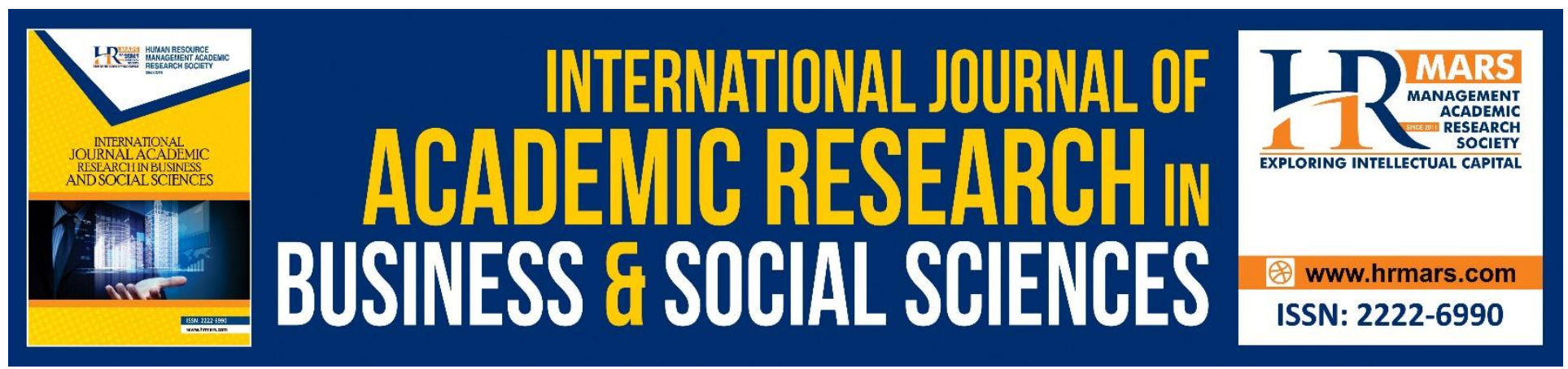

\title{
Relationship between Study Habits and Academic Achievement among Health Science Students
}

\author{
Perimala Silverrajoo and Aminuddin Hassan
}

To Link this Article: http://dx.doi.org/10.6007/IJARBSS/v8-i7/4418

DOI: $\quad 10.6007 /$ IJARBSS/v8-i7/4418

Received: 10 June 2018, Revised: 23 June 2018, Accepted: 29 June 2018

Published Online: 28 July 2018

In-Text Citation: (Silverrajoo \& Hassan, 2018)

To Cite this Article: Silverrajoo, P., \& Hassan, A. (2018). Relationship between Study Habits and Academic Achievement among Health Science Students. International Journal of Academic Research in Business and Social Sciences, 8(7), 763-780.

\section{Copyright: (C) 2018 The Author(s)}

Published by Human Resource Management Academic Research Society (www.hrmars.com)

This article is published under the Creative Commons Attribution (CC BY 4.0) license. Anyone may reproduce, distribute, translate and create derivative works of this article (for both commercial and non-commercial purposes), subject to full attribution to the original publication and authors. The full terms of this license may be seen

at: http://creativecommons.org/licences/by/4.0/legalcode

Vol. 8, No. 7, July 2018, Pg. 763 - 780

http://hrmars.com/index.php/pages/detail/IJARBSS

JOURNAL HOMEPAGE

Full Terms \& Conditions of access and use can be found at http://hrmars.com/index.php/pages/detail/publication-ethics 


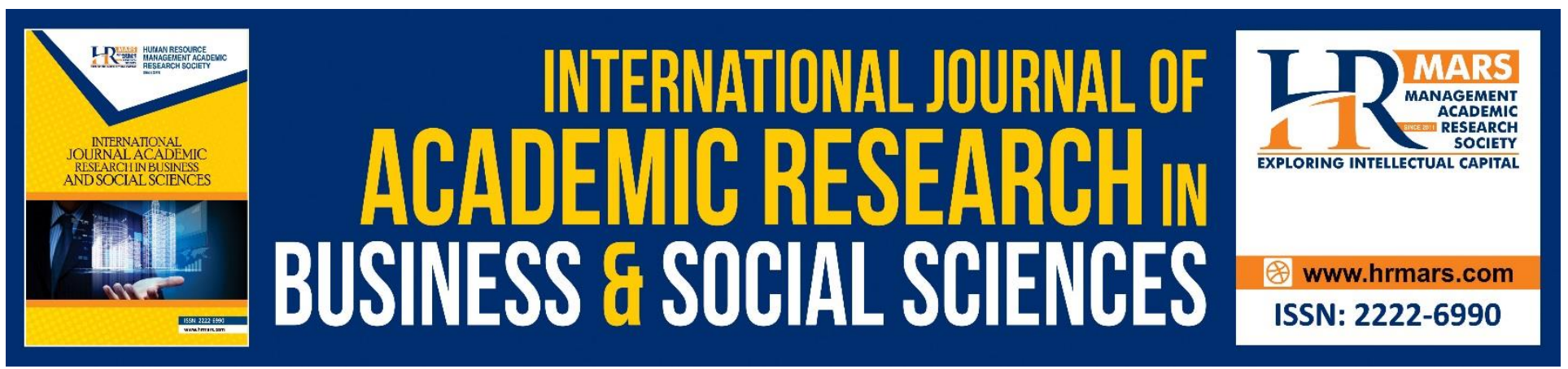

\title{
Relationship between Study Habits and Academic Achievement among Health Science Students
}

\author{
Perimala Silverrajoo and Aminuddin Hassan \\ Faculty of Educational Studies, Universiti Putra Malaysia, 43400 UPM Serdang, Selangor, Malaysia
}

\begin{abstract}
The objective of this study is to identify the relationship between study habits and academic achievements of Health Science Student's in Masterskill University College of Health Sciences. This study also identifies the different study habit used by health science students and the academic achievement of the health science students. The overall health science students who participated in this survey were 150 (125 female and 25 male). Survey method was used in order to collect data through questionnaire. Factor analysis was carried out to group the variables under three different construct (UON, MOS, and Reading). Descriptive statistic was used to determine the different study habit practiced by the health science students and to identify the academic achievements of the health science students. Pearson Correlation analysis was used to view the relationship between underlining, outline summary and note taking (UON), method of study (MOS), and Reading method with the academic achievement of the health science students. The results of this study discovered that majority of the students are using the three different study habits mentioned in the questionnaire and their academic achievement shows that most of them are getting average level of CGPA. In measuring the relationship, the results shows that there is no significant relationship between UON and reading towards the academic achievements of the health science students. Whereby the relationship between MOS shows that there is a significant relationship to the academic achievement but it does not assist the towards the student's academic performance as it shows a negative and weak relationship.
\end{abstract}

Keywords: Study Habits, Academic Achievement, Underline, Outline Summary and Note Taking, Methods of Study, Reading

\section{Introduction}

Health care industry has seen some increase in medical institution and colleges in our country. The increase in these institutions has not only covered hospitals but also institute of education in Malaysia. Information from Department of Statistic, Malaysia (2012) revealed that the Malaysian government places importance on the expansion and development of health care, putting $5 \%$ of the government social sector development budget into public health care-an increase of more than $47 \%$ over the previous figure. This has meant an overall increase of more than RM 2 billion. This proves that the government is showing a keen interest in raising the health science standards in Malaysia 
INTERNATIONAL JOURNAL OF ACADEMIC RESEARCH IN BUSINESS AND SOCIAL SCIENCES

Vol. 8, No. 7, July 2018, E-ISSN: 2222-6990 @ 2018 HRMARS

and to cope with the demand the nation has, it is catering the need to generate the workforce in this expanding industry.

The health science industry consists of many elements of its own which is used widely in providing a complete healthcare expertise. It ranges from physiotherapy lab to occupational health and safety. In a growing nation like Malaysia, the health care institution plays a big role in extending its expertise in benchmarking decisions when it comes to governmental policies and procedures. Being in a position where the industry do not only serve as a point of reference, this aspect of health science management also reflects as an important choice for students to pursue their education in medical and health science studies. With so many students enrolling into medical institution, the level of delivering effective education should not be compromised. For this reason, academic achievement of students should highlight the importance of quality education in Malaysia especially when we talk about health science education.

\section{Problem Statement}

An intellectual measurement of how a student performs depends heavily on how he or she studies. According to Oxford Dictionary \& Thesaurus of English Language, study habit is the tendency of a student to learn in a systematic and efficient way when opportunity is given, (Shabbir Ahmad Rana \& Rukhsana Kausar, 2011). It is also a way of how a student chooses to study in a routinely manner to improve his or her academic performance. Educational psychologists and researchers have argued that there are many determinants of academic performance (Chamorro-Permuzic \& Furnham, 2003). The achievement of students academically though many would perceive as purely from subjects and habits alone, there are also other factors which contributes to such accomplishments. According to Deary, Whiteman, Starr, Whalley, \& Fox (2004), academic performance is a complex student behavior and underlies several abilities, e.g., memory, previous knowledge or aptitude as well as psychological factors such as motivation, interests, temperaments or emotions, to name a few.

Many researchers all over the world, particularly in South East Asian countries have done their analysis thoroughly on factors which enables students to gain better academic performance in studies. It is learnt that these factors or causes that makes students to study better (or less) is derived from study habits. Rasul (1968) and Shafiq (1978) narrated that good study habits generates an overwhelming response when it comes to accomplishing well in exams. So the relationship between good study habits and academic achievement is regarded important to understand of how students gain results. Sorenseon (1991) while outlining the good basic study habits stated that one must study with the primary intention of understanding. The relevancy about understanding what is learnt and what is studied can be taken as two different ways to achieve better grades.

In Malaysia, it is sad to say that our education system is still based on merits where it sometimes leaves no choice to the students but to memorize formulas which are used in exams. They become succumb to the facts without having to understand why they have to do it. This in turn allows poor educational achievements among students. Many students fail not because they lack ability, but because they do not have adequate study skills (Menzel, 1982). The lack of appropriate study skills proves to be a lethal setback for students because they are solely depending on retention techniques alone to gain better results. The problem here is not entirely based on the educational system our country has but more towards the relationship between study habits and academic achievements 
INTERNATIONAL JOURNAL OF ACADEMIC RESEARCH IN BUSINESS AND SOCIAL SCIENCES

Vol. 8, No. 7, July 2018, E-ISSN: 2222-6990 ㄷ 2018 HRMARS

among students. This research examines the relationship between study habits and academic achievement of health science students in Masterskill University College.

It is my hope that through this research, the paradigm in addressing and analyzing the study habits among health science students can be properly defined for the benefit of our future endeavors.

\section{Objective of Study}

In order to enhance the quality of education and academic achievement, it is necessary to improve the study habits of the students.

The purposes of this research are:

1. To identify the difference of study habit among health science students.

2. To identify the academic achievement among health science students.

3. To determine the relationship between students' study habits and academic achievements.

\section{Research Question and Hypothesis}

Below are the research questions which hoped to be answered through this research.

1. What are the different study habits used by health science students?

2. What are the academic achievements of health science students?

3. Is there any relationship between underlining, outline summary and note taking method used by health science students and their academic achievement?

4. Is there any relationship between method of study among health science students and their academic achievement?

5. Is there any relationship between reading method among health science students and their academic achievement?

Based on the research questions above, the following null hypotheses are stated below.

Ho: There is no significant relationship between study habit and academic achievement among health science students at Masterskill University College of Health Sciences.

\section{Significant of Study}

Findings from this study will be very useful for low achieving students, lecturers and the Students Affair Department of MUCH. Besides that, if the findings show that the study habits practiced by the students do not help to increase their grade, it is important for the Students Affair Department and the health science lecturer to determine different study habits that can be practiced by the students (other than the study habits mentioned in the questionnaire).

Furthermore, this findings will encourage the Students Affair Department (with the help of the management of $\mathrm{MUCH}$ ) to conduct programs, seminars and workshops for below average students. As a ramification, it is hoped that Masterskill University College of Health Sciences will produce students who are better equipped with skills and knowledge and competent in the healthcare industry. 
INTERNATIONAL JOURNAL OF ACADEMIC RESEARCH IN BUSINESS AND SOCIAL SCIENCES

Vol. 8, No. 7, July 2018, E-ISSN: 2222-6990 @ 2018 HRMARS

\section{Method}

\section{Sample}

The population in this study includes all health science students in all the faculty at Masterskill University College of Health Sciences, Cheras Campus. The samples selected for this research was the health science students from four different faculties in Masterskill University College of Health Sciences. The faculties are Faculty of Biomedicine \& Health, Faculty of Pharmacy, Faculty of Therapeutic Science and Faculty of Nursing. The population of health science students at Masterskill University College of Health Scienec is around 1500, which is moderately a large population. Therefore, about $10 \%$ from the population are needed for the sampling. As a result, the sample size which was selected was 150 . Simple random sampling method was used in this study to choose the sample from the population.

\section{Instrument}

Questionnaire was used as an instrument in this research. Students who participated in this research were given consent forms along with the questionnaire in order to get the participants to answer the questionnaire on voluntary basis. 4 likert scales ( 1 = never, $2=$ sometimes, $3=$ usually and $4=$ always) was used in order to help the students to choose their answer to their favor. The total number of questions in the questionnaire is 35 and it is a modified form of Study Skill Assessment Questionnaire created by the Department of Counseling Services, University of Houston Clear Lake (2008) which was used to measure the study skill practiced by the students at University of Houston Clear Lake, Texas. Section C (Reading), section E (Underlining, outline summary and note taking) and section $F$ (Method of study) from the Study Skill Assessment Questionnaire was used by the researcher in this study.

The questionnaire used by the researcher in this study was based on the following sections.

a) Section A: Demographic Factors

b) Section B: Study Habits: Underlining, Outline Summary and Note Taking

c) Section C: Study Habits: Method of Study

d) Section D: Study Habits: Reading

\section{Data Analysis}

The data collected for this study were analyzed using descriptive analysis, and Pearson's Correlation through SPSS version 16. Descriptive analysis was used in order to answer research question one and two to find the mean, frequency and standard deviation of the variables. This analysis will assist in describing samples from the data collected (Tom Lang, 2003). Pearson Correlation analysis was used to answer research question three, four and five. Correlation is a method used to measure the connection of independent and dependent variables (Kuzma \& Bohnenblust, 2004).

\section{Readability Test}

Readability test was done to the questionnaire using Microsoft word to identify the ease reading level. Following are the result of the readability test: 
INTERNATIONAL JOURNAL OF ACADEMIC RESEARCH IN BUSINESS AND SOCIAL SCIENCES

Vol. 8, No. 7, July 2018, E-ISSN: 2222-6990 @ 2018 HRMARS

Table 1: Readability Test Score

\begin{tabular}{|l|c|}
\hline \multicolumn{1}{|c|}{ Readability } & Result \\
\hline Flesch Reading Ease & 67.6 \\
\hline Flesch-Kincaid Grade & 6 \\
\hline
\end{tabular}

Table 1 explain that this questionnaire can be read and understood by students in grade 6 . Therefore, health science students at Masterskill University College of Health Sciences would not have any problem in reading and understanding the questionnaire.

\section{Pilot Study}

\section{Readability Test}

Validity and reliability of the study habit questionnaire were determined to ensure that the instrument is suitable for the Health Science students. In order to ensure the questionnaire is suitable, the questionnaire was administered through pilot test. This pilot test was done to identify the reliability of the questionnaire by determining the consistence in answering by the individual choose (Creswell, 2005). This pilot test was administered to 30 health science students from one of the faculties (Faculty of Biomedicine and Health).

Reliability test for the study habit questionnaire was conducted for section B (Underlining, Outline Summary and Note Taking), section C (Method of Study) and section D (Reading). All these sections consist of 10 questions each. The Cronbach's alpha value for section B is 0.702 , section C is 0.797 and section $D$ is 0.776 . The correlation value for all 10 questions in each sections shows the Cronnach's Alpha range below the Cronbach's Alpha value. Thus no question deleted since it does not significantly improve the Cronbach's Alpha value. All these questions are used for the real test which was conducted to study the relationship of study habits and the academic achievement of the students.

\section{Findings}

The findings of the research are analyzed by answering the research questions. Table 2 provide demographic information of the samples. The result of the table indicates that the age of students who participate in answering the questionnaire are from 19 years to 30 years old. Most of the students $(n=39)$ are 22 years old $(25.5 \%)$ and only one student reported to be 30 years of age $(0.7 \%)$. The table also shows that majority of students are female. $83.3 \%(n=125)$ were female while $16.6 \%$ $(n=25)$ were male students.

The ethnicity information of the participants explain that $54.2 \%(n=83)$ are Malay students, $2.6 \%(n$ $=4)$ are Chinese students, $28.8 \%(n=44)$ students are Indian and $12.4 \%(n=19)$ are students under other category of ethnic. Besides that information on religion of the participants clarify that the $55.6 \%$ $(n=85)$ students are Muslim. Only 2\% $(n=4)$ students are Buddhist, $27.5 \%(n=42)$ are Hindu students, $11.1 \%(n=17)$ students are Christian and the balance $2 \%(n=3)$ of students are from others group of religion. 
INTERNATIONAL JOURNAL OF ACADEMIC RESEARCH IN BUSINESS AND SOCIAL SCIENCES Vol. 8, No. 7, July 2018, E-ISSN: 2222-6990 (C) 2018 HRMARS

In terms of grade, majority of students (43.8\%) obtain CGPA above 2.75 . Around $24.8 \%(n=38)$ students get CGPA above 1.75 and $29.4 \%(n=45)$ attain CGPA above 3.33

Table 2: Demographic Information of Respondents

\begin{tabular}{|c|c|c|c|}
\hline Measure & Description & Frequency & $\%$ \\
\hline Age & $\begin{array}{l}19 \text { years old } \\
20 \text { years old } \\
21 \text { years old } \\
22 \text { years old } \\
23 \text { years old } \\
24 \text { years old } \\
25 \text { years old } \\
26 \text { years old } \\
27 \text { years old } \\
29 \text { years old } \\
30 \text { years old }\end{array}$ & $\begin{array}{c}13 \\
37 \\
23 \\
39 \\
18 \\
8 \\
4 \\
2 \\
3 \\
2 \\
1\end{array}$ & $\begin{array}{c}8.5 \\
24.2 \\
15.0 \\
25.5 \\
11.8 \\
5.2 \\
2.6 \\
1.3 \\
2.0 \\
1.3 \\
0.7\end{array}$ \\
\hline Total & & 150 & 100 \\
\hline Gender & $\begin{array}{l}1=\text { Male } \\
2=\text { Female }\end{array}$ & $\begin{array}{c}25 \\
125\end{array}$ & $\begin{array}{l}16.6 \\
83.3\end{array}$ \\
\hline Total & & 150 & 100 \\
\hline Ethnicity & $\begin{array}{l}1=\text { Malay } \\
2=\text { Chinese } \\
3=\text { Indian } \\
4=\text { Others }\end{array}$ & $\begin{array}{c}83 \\
4 \\
44 \\
19\end{array}$ & $\begin{array}{c}54.2 \\
2.6 \\
28.8 \\
12.4\end{array}$ \\
\hline Total & & 150 & 100 \\
\hline Religion & $\begin{array}{l}1=\text { Muslim } \\
2=\text { Buddhist } \\
3=\text { Hindu } \\
4=\text { Christian } \\
5=\text { Others }\end{array}$ & $\begin{array}{c}85 \\
3 \\
42 \\
17 \\
3\end{array}$ & $\begin{array}{c}55.6 \\
2.0 \\
27.5 \\
11.1 \\
2.0\end{array}$ \\
\hline Total & & 150 & 100 \\
\hline Grade (GCPA) & $\begin{array}{l}1=>1.75 \\
2=>2.75 \\
3=>3.33\end{array}$ & $\begin{array}{l}38 \\
67 \\
45\end{array}$ & $\begin{array}{l}24.8 \\
43.8 \\
29.4\end{array}$ \\
\hline Total & & 150 & 100 \\
\hline
\end{tabular}

1. What are the different study habits used by health science students? 
INTERNATIONAL JOURNAL OF ACADEMIC RESEARCH IN BUSINESS AND SOCIAL SCIENCES

Vol. 8, No. 7, July 2018, E-ISSN: 2222-6990 @ 2018 HRMARS

The result display that more than $50 \%$ of students do underline, outline summary, and take note when they are studying. Students always underline the important points $(M=3.373, S D=0.790)$, usually write notes on the margin $(M=46.4, S D=0.744)$ and they use it to draw and outline a diagram. However, $45.8 \%(M=2.286, S D=0.821)$ of students state that they write the summary immediately without underlining and outlining. Besides that, $58.8 \%$ of students informed that they disagree to the statement saying underlining, outlining and writing summary are a waste of time. This can be due to the fact that in order to understand what is learnt, students feel it is very important to give special attention and focus to reinforce learning. From this table, we can analyze that there are many ways students use to underline, writing summaries and note taking techniques that enhance the absorption power in students that proves to be a very important tool to most students today.

Table 3: Differences in Underlining, Outline Summary and Note Taking Methods Used by Health Science Students

\begin{tabular}{|c|c|c|c|c|c|c|c|}
\hline No & Item & NVR & ST & USL & ALW & Mean & SD \\
\hline & & $F(\%)$ & $F(\%)$ & $F(\%)$ & $F(\%)$ & & \\
\hline 1. & $\begin{array}{l}\text { When I study a } \\
\text { theme I underline } \\
\text { the important ideas } \\
\text { or data. }\end{array}$ & $\begin{array}{c}2 \\
(1.3)\end{array}$ & $\begin{array}{c}23 \\
(15.0)\end{array}$ & $\begin{array}{c}42 \\
(27.5)\end{array}$ & $\begin{array}{c}83 \\
(54.2)\end{array}$ & 3.373 & 0.790 \\
\hline 2. & $\begin{array}{l}\text { When study I write } \\
\text { notes on the } \\
\text { margins. }\end{array}$ & $\begin{array}{c}2 \\
(1.3)\end{array}$ & $\begin{array}{c}46 \\
(30.1)\end{array}$ & $\begin{array}{c}71 \\
(46.4)\end{array}$ & $\begin{array}{c}31 \\
(20.3)\end{array}$ & 2.873 & 0.744 \\
\hline 3. & $\begin{array}{l}\text { I underline only what } \\
\text { I understand. }\end{array}$ & $\begin{array}{c}16 \\
(10.5) \\
\end{array}$ & $\begin{array}{c}42 \\
(27.5) \\
\end{array}$ & $\begin{array}{c}50 \\
(32.7) \\
\end{array}$ & $\begin{array}{c}42 \\
(27.5) \\
\end{array}$ & 2.786 & 0.973 \\
\hline 4. & $\begin{array}{l}\text { I outline or draw } \\
\text { diagrams of the } \\
\text { themes I study. }\end{array}$ & $\begin{array}{c}7 \\
(4.6)\end{array}$ & $\begin{array}{c}66 \\
(43.1)\end{array}$ & $\begin{array}{c}60 \\
(39.2)\end{array}$ & $\begin{array}{c}17 \\
(11.1)\end{array}$ & 2.580 & 0.816 \\
\hline 5. & $\begin{array}{l}\text { To outline or draw } \\
\text { diagrams, I use the } \\
\text { underlining and the } \\
\text { notes I took in class }\end{array}$ & $\begin{array}{c}11 \\
(7.2)\end{array}$ & $\begin{array}{c}34 \\
(22.2)\end{array}$ & $\begin{array}{c}78 \\
(51.0)\end{array}$ & $\begin{array}{c}27 \\
(17.6)\end{array}$ & 2.806 & 0.816 \\
\hline 6. & $\begin{array}{l}\text { In the summary I use } \\
\text { my own words. }\end{array}$ & $\begin{array}{c}7 \\
(4.6)\end{array}$ & $\begin{array}{c}51 \\
(33.3) \\
\end{array}$ & $\begin{array}{c}40 \\
(26.7)\end{array}$ & $\begin{array}{c}52 \\
(34.0) \\
\end{array}$ & 2.913 & 0.933 \\
\hline 7. & $\begin{array}{l}\text { I write the summary } \\
\text { immediately, without } \\
\text { underlining or } \\
\text { outlining. }\end{array}$ & $\begin{array}{c}24 \\
(15.7)\end{array}$ & $\begin{array}{c}70 \\
(45.8)\end{array}$ & $\begin{array}{c}45 \\
(29.4)\end{array}$ & $\begin{array}{c}11 \\
(7.2)\end{array}$ & 2.286 & 0.821 \\
\hline
\end{tabular}


INTERNATIONAL JOURNAL OF ACADEMIC RESEARCH IN BUSINESS AND SOCIAL SCIENCES Vol. 8, No. 7, July 2018, E-ISSN: 2222-6990 @ 2018 HRMARS

\begin{tabular}{|l|l|c|c|c|c|c|c|}
\hline 8. & $\begin{array}{l}\text { I think underlining, } \\
\text { outlining and writing } \\
\text { summary are a waste } \\
\text { of time. }\end{array}$ & $\begin{array}{c}90 \\
(58.8)\end{array}$ & $\begin{array}{c}31 \\
(20.3)\end{array}$ & $\begin{array}{c}24 \\
(15.7)\end{array}$ & $\begin{array}{c}5 \\
(3.3)\end{array}$ & 1.626 & 0.871 \\
\hline 9. & $\begin{array}{l}\text { In the classes I take } \\
\text { notes from what the } \\
\text { teacher explains. }\end{array}$ & $\begin{array}{c}1 \\
(0.7)\end{array}$ & $\begin{array}{c}17 \\
(11.1)\end{array}$ & $\begin{array}{c}56 \\
(36.6)\end{array}$ & $\begin{array}{c}76 \\
(49.7)\end{array}$ & 3.380 & 0.711 \\
\hline 10. & $\begin{array}{l}\text { When I take notes I } \\
\text { use my own } \\
\text { abbreviations. }\end{array}$ & $\begin{array}{c}2 \\
(1.3)\end{array}$ & $\begin{array}{c}37 \\
(24.7)\end{array}$ & $\begin{array}{c}48 \\
(32.0)\end{array}$ & $\begin{array}{c}63 \\
(42.0)\end{array}$ & 3.146 & 0.838 \\
\hline
\end{tabular}

Table 4 shows result on the different method of study that was practice by the health science students. This explains that as many as $46.4 \% \quad(M=3.20, S D=0.889)$ of students always read all the questions of the test before beginning to answer it and $43.8 \%(M=3.16, S D=0.742)$ of students agree that before learning, usually they have to understand what they are reading. $44.4 \%(\mathrm{M}=2.506$, $\mathrm{SD}=0.783$ ) of students mentioned that only sometimes they use other reference books beside the clarified book to increase their knowledge. However, 45.1\% ( $\mathrm{M}=2.540, \mathrm{SD}=0.742)$ students mentioned that only sometimes they revise their subjects frequently. It is observed that from the percentage gained, students have the tendencies to read all the questions first before deciding to answer it. This proves the understanding level of students in achieving better insight about studies is taken very seriously. Students are finding new ways to not only study effectively but also in achieving an efficient way of implementing what is studied. So, the different approaches in studying are used widely in acquiring good concentration level and undivided focus when it comes to studies.

Table 4: Differences in Method of Study Practice by Health Science Students

\begin{tabular}{|c|c|c|c|c|c|c|c|}
\hline No & Item & NVR & ST & USL & ALW & Mean & SD \\
\hline & & $F(\%)$ & $F(\%)$ & $F(\%)$ & $F(\%)$ & & \\
\hline 1. & $\begin{array}{l}\text { When I don`t } \\
\text { understand something I } \\
\text { ask the teachers }\end{array}$ & $\begin{array}{c}1 \\
(0.7)\end{array}$ & $\begin{array}{c}68 \\
(44.4)\end{array}$ & $\begin{array}{c}41 \\
(26.8)\end{array}$ & $\begin{array}{c}40 \\
(26.1)\end{array}$ & 2.800 & 0.843 \\
\hline 2. & $\begin{array}{l}\text { I exchange views with } \\
\text { my classmates about } \\
\text { what we study. }\end{array}$ & $\begin{array}{c}1 \\
(0.7)\end{array}$ & $\begin{array}{c}50 \\
(32.7)\end{array}$ & $\begin{array}{c}64 \\
(35)\end{array}$ & $\begin{array}{c}35 \\
(22.9)\end{array}$ & 2.886 & 0.764 \\
\hline 3. & $\begin{array}{l}\text { In my exercises or } \\
\text { study-works I } \\
\text { concentrate on others } \\
\text { which are already } \\
\text { corrected. }\end{array}$ & $\begin{array}{c}5 \\
(3.3)\end{array}$ & $\begin{array}{c}53 \\
((34.6)\end{array}$ & $\begin{array}{c}71 \\
(46.4)\end{array}$ & $\begin{array}{c}21 \\
(13.7)\end{array}$ & 2.720 & 0.742 \\
\hline 4. & $\begin{array}{l}\text { When I finish a test I } \\
\text { read it again before } \\
\text { handing it. }\end{array}$ & $\begin{array}{c}4 \\
(2.6)\end{array}$ & $\begin{array}{c}29 \\
(19.0)\end{array}$ & $\begin{array}{c}52 \\
(34.0)\end{array}$ & $\begin{array}{c}65 \\
(43.3)\end{array}$ & 3.186 & 0.838 \\
\hline 5. & $\begin{array}{l}\text { When I study, I use } \\
\text { other books besides }\end{array}$ & $\begin{array}{c}11 \\
(7.2)\end{array}$ & $\begin{array}{c}68 \\
(44.4)\end{array}$ & $\begin{array}{c}55 \\
(35.9)\end{array}$ & $\begin{array}{c}16 \\
(10.5)\end{array}$ & 2.506 & 0.783 \\
\hline
\end{tabular}


INTERNATIONAL JOURNAL OF ACADEMIC RESEARCH IN BUSINESS AND SOCIAL SCIENCES Vol. 8, No. 7, July 2018, E-ISSN: 2222-6990 @ 2018 HRMARS

\begin{tabular}{|c|c|c|c|c|c|c|c|}
\hline & $\begin{array}{l}\text { the adopted book to } \\
\text { clarify or } \\
\text { widen/increase } \\
\text { knowledge. }\end{array}$ & & & & & & \\
\hline 6. & $\begin{array}{l}\text { I revise frequently so as } \\
\text { not to forget what I } \\
\text { have learnt. }\end{array}$ & $\begin{array}{c}7 \\
(4.6)\end{array}$ & $\begin{array}{c}69 \\
(45.1)\end{array}$ & $\begin{array}{c}60 \\
(39.2)\end{array}$ & $\begin{array}{c}14 \\
(9.2)\end{array}$ & 2.540 & 0.742 \\
\hline 7. & $\begin{array}{l}\text { To learn something I } \\
\text { have to understand it } \\
\text { before. }\end{array}$ & $\begin{array}{c}1 \\
(0.7)\end{array}$ & $\begin{array}{c}28 \\
(18.3)\end{array}$ & $\begin{array}{c}67 \\
(43.8)\end{array}$ & $\begin{array}{c}54 \\
(35.3)\end{array}$ & 3.16 & 0.742 \\
\hline 8. & $\begin{array}{l}\text { I read all the questions } \\
\text { of the test before } \\
\text { beginning to answer it. }\end{array}$ & $\begin{array}{c}6 \\
(3.9)\end{array}$ & $\begin{array}{c}29 \\
(19.0)\end{array}$ & $\begin{array}{c}44 \\
(28.8)\end{array}$ & $\begin{array}{c}71 \\
(46.4)\end{array}$ & 3.200 & 0.889 \\
\hline 9. & $\begin{array}{l}\text { When I have to do } \\
\text { some study-work, } \\
\text { before beginning I read } \\
\text { a lot about the theme, } \\
\text { organize the ideas and } \\
\text { write an outline. }\end{array}$ & $\begin{array}{c}5 \\
(3.3)\end{array}$ & $\begin{array}{c}48 \\
(31.4)\end{array}$ & $\begin{array}{c}66 \\
(43.1)\end{array}$ & $\begin{array}{c}31 \\
(20.3)\end{array}$ & 2.820 & 0.794 \\
\hline 10. & $\begin{array}{l}\text { I ask questions on what } \\
\text { I study and try to } \\
\text { answer them. }\end{array}$ & $\begin{array}{c}8 \\
(5.2)\end{array}$ & $\begin{array}{c}49 \\
(32.0)\end{array}$ & $\begin{array}{c}55 \\
(35.9)\end{array}$ & $\begin{array}{c}38 \\
(24.8)\end{array}$ & 2.820 & 0.875 \\
\hline
\end{tabular}

Table 5 reports the difference in reading method practiced by the students are mostly in high level. Results shows that $52.3 \%(\mathrm{M}=2.693, \mathrm{SD}=0.644)$ usually can find the main ideas easily while reading. Meanwhile, $53.6 \%$ ( $M=2.860, S D=0.733$ ) students can usually point out where they are easily. Besides that, as many as $42.5 \%$ of students indicate that they go through the topics quickly before start studying ( $M=2.633, S D=0.854), 40.5 \%$ students use dictionary sometimes while they study ( $M$ $=2.593, \mathrm{SD}=0.786$ ) and $40.5 \%$ of students only sometimes prepare in advance on the topics that are about to be explained in class by the lecturer. The different reading methods used by students best describes how students enforce the learning ability in affirming the contents which is read. Human's mind work very effectively when it is exposed to pictures and graphics. It has a better understanding and recalls ability because the mind seeks its way to narrate information through picture association. If we study the table closely, it would reveal that students use this technique to understand what is studied for profound results. 
INTERNATIONAL JOURNAL OF ACADEMIC RESEARCH IN BUSINESS AND SOCIAL SCIENCES Vol. 8, No. 7, July 2018, E-ISSN: 2222-6990 (C) 2018 HRMARS

Table 5: Differences in Reading Method Practiced among Health Science Students

\begin{tabular}{|c|c|c|c|c|c|c|c|}
\hline No & Item & NVR & ST & USL & ALW & Mean & SD \\
\hline & & $F(\%)$ & $F(\%)$ & $F(\%)$ & $F(\%)$ & & \\
\hline 1. & $\begin{array}{l}\text { Before starting } \\
\text { studying I go through } \\
\text { the topic quickly. }\end{array}$ & $\begin{array}{c}9 \\
(5.9)\end{array}$ & $\begin{array}{c}65 \\
(42.5)\end{array}$ & $\begin{array}{c}48 \\
(31.4)\end{array}$ & $\begin{array}{c}28 \\
(18.3)\end{array}$ & 2.633 & 0.854 \\
\hline 2. & $\begin{array}{l}\text { I find the main ideas } \\
\text { easily. }\end{array}$ & $\begin{array}{c}2 \\
(1.3)\end{array}$ & $\begin{array}{c}55 \\
(35.9)\end{array}$ & $\begin{array}{c}80 \\
(52.3)\end{array}$ & $\begin{array}{c}13 \\
(8.5)\end{array}$ & 2.693 & 0.644 \\
\hline 3. & I enjoy reading. & $\begin{array}{c}6 \\
(3.9)\end{array}$ & $\begin{array}{c}45 \\
(29.4) \\
\end{array}$ & $\begin{array}{c}71 \\
(46.4) \\
\end{array}$ & $\begin{array}{c}28 \\
(18.3) \\
\end{array}$ & 2.806 & 0.783 \\
\hline 4. & $\begin{array}{l}\text { I just read what the } \\
\text { teachers tell me to. }\end{array}$ & $\begin{array}{c}7 \\
(4.6)\end{array}$ & $\begin{array}{c}56 \\
(36.6)\end{array}$ & $\begin{array}{c}50 \\
(32.7)\end{array}$ & $\begin{array}{c}37 \\
(24.2)\end{array}$ & 2.780 & 0.873 \\
\hline 5. & $\begin{array}{l}\text { To learn I have to } \\
\text { read the subjects } \\
\text { aloud. }\end{array}$ & $\begin{array}{c}20 \\
(13.1)\end{array}$ & $\begin{array}{c}43 \\
(28.1)\end{array}$ & $\begin{array}{c}54 \\
(35.3)\end{array}$ & $\begin{array}{c}32 \\
(20.9)\end{array}$ & 2.860 & 2.657 \\
\hline 6. & $\begin{array}{l}\text { When I study I } \\
\text { concentrate on the } \\
\text { pictures and } \\
\text { graphics. }\end{array}$ & $\begin{array}{c}6 \\
(3.9)\end{array}$ & $\begin{array}{c}46 \\
(30.1)\end{array}$ & $\begin{array}{c}52 \\
(34.0)\end{array}$ & $\begin{array}{c}46 \\
(30.1)\end{array}$ & 2.920 & 0.878 \\
\hline 7. & $\begin{array}{l}\text { While I read I point } \\
\text { out where I am. }\end{array}$ & $\begin{array}{c}5 \\
(3.3)\end{array}$ & $\begin{array}{c}37 \\
(24.2)\end{array}$ & $\begin{array}{c}82 \\
(53.6)\end{array}$ & $\begin{array}{c}26 \\
(17.0)\end{array}$ & 2.860 & 0.733 \\
\hline 8. & $\begin{array}{l}\text { I often use the } \\
\text { dictionary while I } \\
\text { study. }\end{array}$ & $\begin{array}{c}9 \\
(5.9)\end{array}$ & $\begin{array}{c}62 \\
(40.5)\end{array}$ & $\begin{array}{c}60 \\
(39.2)\end{array}$ & $\begin{array}{c}19 \\
(12.4)\end{array}$ & 2.593 & 0.786 \\
\hline 9. & $\begin{array}{l}\text { I prepare in advance } \\
\text { the topics that are } \\
\text { about to be } \\
\text { explained in the } \\
\text { class. }\end{array}$ & $\begin{array}{c}11 \\
(7.2)\end{array}$ & $\begin{array}{c}62 \\
(40.5)\end{array}$ & $\begin{array}{c}59 \\
(38.6)\end{array}$ & $\begin{array}{c}18 \\
(11.8)\end{array}$ & 2.560 & 0.798 \\
\hline 10. & $\begin{array}{l}\text { If there is something } \\
\text { I don't understand, I } \\
\text { mark it and ask the } \\
\text { teacher or a } \\
\text { classmate. }\end{array}$ & $\begin{array}{c}8 \\
(5.2)\end{array}$ & $\begin{array}{c}42 \\
(27.5)\end{array}$ & $\begin{array}{c}54 \\
(35.3)\end{array}$ & $\begin{array}{c}46 \\
(30.1)\end{array}$ & 2.920 & 0.893 \\
\hline \multicolumn{8}{|c|}{ Note: $\boldsymbol{N} \boldsymbol{V} \boldsymbol{R}=$ Never, $\boldsymbol{S T}=$ Sometimes, $\boldsymbol{U S L}=$ Usually, $\mathbf{A L W}=$ Always } \\
\hline
\end{tabular}

2. What are the level of academic achievements of health science students?

The result of the analysis shows that only $30 \%$ out of 150 students who represent the whole population of the college are good or high achievers. However, $44.7 \%$ are average students and the 
INTERNATIONAL JOURNAL OF ACADEMIC RESEARCH IN BUSINESS AND SOCIAL SCIENCES Vol. 8, No. 7, July 2018, E-ISSN: 2222-6990 @ 2018 HRMARS

balance $25 \%$ is below average students. Most of students are under average category. This is probably because the students are not applying proper study habit and they may be very dependent on lecturers to supply them with answers.

Table 6: Academic Achievement of Health Science Students

\begin{tabular}{|c|l|c|c|c|c|}
\hline & \multicolumn{1}{|c|}{ CGPA } & Frequency & Percent & Valid Percent & $\begin{array}{c}\text { Cumulative } \\
\text { Percent }\end{array}$ \\
\hline Valid & $\begin{array}{l}\text { Good } \\
(3.33-4.00)\end{array}$ & 45 & 30.0 & 30.0 & 30.0 \\
\cline { 2 - 6 } & $\begin{array}{l}\text { Average } \\
(2.75-3.32)\end{array}$ & 67 & 44.7 & 44.7 & 74.7 \\
\cline { 2 - 6 } & $\begin{array}{l}\text { Below Average } \\
(0.00-2.74)\end{array}$ & 38 & 25.3 & 25.3 & 100.0 \\
\cline { 2 - 6 } & Total & 150 & 100.0 & 100.0 & \\
\hline
\end{tabular}

3. Is there any relationship between underlining, outline summary and note taking

(UON) of health science students and their academic achievement?

Pearson's correlation coefficients analysis was used to test this relationship between underlining, outline summary, and note taking (UON) with academic achievements. It shows a negative correlation and there is no significant relationship between underlining, outline summary, and note taking (UON) with academic achievements of the students $(r=-0.072 ; p<0.01)$.

It was understood that even thought the students are practicing this method but it does not assist the students in getting better results. The students might not fully utilize underlining, outlining summary as well as note taking as a method to achieve better results academically even though they practiced it. This is probably because the students are not mainly in favor of utilizing the above methods due to time constraint and routine habits from peers. The vast majority of students who are studying together would not practice the mentioned methods so the possibility of other students to embark new ways to gain better marks is close to zero.

Table 7: Correlation Analysis between Underlining, Outline Summary and Note Taking with Academic Achievements 
INTERNATIONAL JOURNAL OF ACADEMIC RESEARCH IN BUSINESS AND SOCIAL SCIENCES Vol. 8, No. 7, July 2018, E-ISSN: 2222-6990 @ 2018 HRMARS

\begin{tabular}{|ll|r|r|}
\hline & & Level of student grade & UON \\
\hline Level of student & Pearson Correlation & 1 & -.072 \\
grade & Sig. (2-tailed) & 150 & .380 \\
& $\mathrm{~N}$ & -.072 & 150 \\
\hline UON & Pearson Correlation & .380 & 1 \\
& Sig. (2-tailed) & 150 & 150 \\
\hline
\end{tabular}

4. Is there any relationship between method of study (MOS) among health science students and their academic achievement?

Pearson's correlation coefficients analysis was used to test this relationship which is between methods of study (MOS) used by the health science students and their academic achievements. The table shows a negative correlation between the relationship among method of study (MOS) and academic achievements of health science students. The relationship between method of study (MOS) and academic achievement of the health science students is significant $(r=-0.337 ; p<0.01)$.

This explains that there is a relationship between MOS and academic achievement but it is a negative relationship. It detail, when students use more method of study, their grade is reducing and when the students use less method of study, their grade increases. Besides that, the $r$ value indicates a weak correlation since it is less than 0.5 . This result indicates that students are wisely practicing these methods of study but not scoring high marks in their exams.

Table 8: Correlation Analysis between Method of Study (MOS) among health science students and their academic achievements

\begin{tabular}{|ll|r|r|}
\hline & & Level of student grade & \multicolumn{2}{|c|}{ MOS } \\
\hline Level of student & Pearson Correlation & 1 & $-.337^{* *}$ \\
grade & Sig. (2-tailed) & 150 & .000 \\
& $\mathrm{~N}$ & $-.337^{* *}$ & 150 \\
\hline MOS & Pearson Correlation & .000 & 1 \\
& Sig. (2-tailed) & 150 & 150 \\
& $\mathrm{~N}$ & & 150 \\
\end{tabular}

**. Correlation is significant at the 0.01 level (2-tailed).

5. Is there any relationship between reading method among health science students and their academic achievement? 
INTERNATIONAL JOURNAL OF ACADEMIC RESEARCH IN BUSINESS AND SOCIAL SCIENCES Vol. 8, No. 7, July 2018, E-ISSN: 2222-6990 @ 2018 HRMARS

Pearson's correlation coefficients analysis was used to test the relationship between reading method of health science students and their academic achievements. The result shows a negative correlation and there is no significant relationship between reading method of health science students and their academic achievement $(r=-0.113 ; p<0.01)$.

These results clearly explain that not many students go through the topics before they start studying. Students did not enjoy reading all the time. They only enjoy reading sometimes when they find certain topics or chapters are interesting for them and probably they are reading just to pass the exams. Most of the students also reported that they usually and always read only what the teacher told them to read. Many students reported that they do not use dictionary very often when they are studying.

Table 9: Correlation Analysis between Reading Method of Health Science Students and Their Academic Achievements

\begin{tabular}{|ll|r|r|}
\hline & & Level of student grade & READING \\
\hline Level of student & Pearson Correlation & 1 & -.113 \\
grade & & .168 \\
& Sig. (2-tailed) & 150 & 150 \\
& $\mathrm{~N}$ & -.113 & 1 \\
\hline READING & Pearson Correlation & .168 & 150 \\
& Sig. (2-tailed) & 150 & $\mathrm{~N}$ \\
& $\mathrm{~N}$ & & \\
\end{tabular}

\section{Discussion}

1. What are the different study habits used by health science students?

As we can see in section $B$, health science students are practicing most of the variables in underlining, outline summary and note taking methods. Students also agree that this method is not a waste of time. There is only one student from the whole 150 that participated in the research mentioned that the student never take notes from what has been explained in the class and this shows that the other students are practicing it. Few students have highlighted that they write the summary immediately, without underlining or outlining and this is probably because they cannot find the important points by themselves and would always miss out or get the wrong key point.

In section $\mathrm{C}$, the results shows that many students are using all the method of studying mentioned. These students are concentrating on the work which is already corrected and they study it again as one of their method of study. This is probably because the particular work has already been discussed in the class and the correct answer was given. Many students always and usually discuss the subjects with their friends or classmates compared to the numbers of students who prefer to ask questions to the lectures in class. Students sometimes are afraid to ask question to the lecturers and feel comfortable in discussing with their friends and getting their ideas. Many students also indicates that 
INTERNATIONAL JOURNAL OF ACADEMIC RESEARCH IN BUSINESS AND SOCIAL SCIENCES

Vol. 8, No. 7, July 2018, E-ISSN: 2222-6990 ㄷ 2018 HRMARS

they read all the test questions before they start answering it and read it again after answering and before handling it.

Result in section D point out that many health science students are applying reading method while studying. Most of the students mentioned that they can find the main idea easily while reading and they also enjoy reading. Students also mentioned that many of them just read what the teachers ask them to read. This may be because the students are only concentrating mainly on the points given by the teachers and do not find extra information from other reference books.

2. What are the level of academic achievements of health science students?

The student's grade was categorized into three which is good, average and below average. This will identify the different level of grade that was achieved by the students. The result shows that majority of health science students are average students who falls under 2.75 to 3.32 level of CGPA (44.7\%). Students who get good level of CGPA are only about $30 \%$ and the balance $25 \%$ are below average students. Research question one revealed that most of the students are practicing UON, MOS and reading method but majority of them did not get good level of CGPA. This probably happen because students are not always using this methods and was practicing it usually and sometimes only. Hence the result shows that the students are using the study habit methods but did not use it always. There are also few students who did not practicing the study habits and possibly they are the students who fall under below average category.

3. Is there any relationship between underlining, outline summary and note taking method used by health science students and their academic achievement?

Research question three was answered in order to determine whether there is significant relationship between underlining, outline summary and note taking and academic achievement. The result shows that there is no significant relationship ( $r=-0.072 ; p<0.01)$. The result indicates that even though the students are using underlining, outline summary and note taking, but it does not reflect on the student's academic achievement. This result does support the findings done by Raymond W. Preiss and Barbara M. Gayle, (1997) which fails to identify the relationship between note taking and academic achievement of the students.

4. Is there any relationship between method of study among health science students and their academic achievement?

In answering this question, the result indicate a significant relationship between method of study among health science students and their academic achievement $(r=-0.337 ; p<0.01)$ but it do not facilitate the students in increasing their academic performance since it is a negative and weak relationship. This result proves that asking questions to the teachers and discussing subjects with friend do not help the students in improving their academic grade besides practicing the other method of study. This research result contradict from the findings obtained by Marcus Crede and Nathan R. Kuncel, (2008) which conclude that there is significant relationship between study method and academic achievement. 
INTERNATIONAL JOURNAL OF ACADEMIC RESEARCH IN BUSINESS AND SOCIAL SCIENCES

Vol. 8, No. 7, July 2018, E-ISSN: 2222-6990 ㄷ 2018 HRMARS

5. Is there any relationship between reading method among health science students and their academic achievement?

Findings in answering this question show that there is no significant relationship between reading method and academic achievement of health science students $(r=-0.113 ; p<0.01)$. This indicates that the reading methods practiced by the students do not significantly increase or reduce their academic grade. This may be because the students are very much interested in studying only the points given by the teachers and not self reading. These studies contradict with the findings by Kathleen and Collins (2006) which stated in his findings that reading method is significant predictor of academic achievement.

\section{Conclusion}

As a whole, findings from this research partially support the researcher's hypothesis. It is discovered that only method of study used by the students have significant relationship with academic achievements of the health science students. However it does not help to increase the student's academic performance. Underlining, outline summary, note taking and reading method used by the students do not have significant relationship with academic achievement of students and does not influence the student's grade level. Therefore, findings shows that students are more interested in discussing problems they face in any subject with their classmates or friends and concentrating as well as revising works which is already corrected. Besides that, reading all questions before start answering test paper, checking the test answer before handling it and revising subjects using other reference book was also the methods of study commonly practiced by the students.

This does not mean that the other study habit never helped the students in raising their grade but students may not know whether points they underline is right or wrong and dependent to the lecturer in delivering answers to all the works, tutorials and test. Students can only see the significant relationship in reading method and their academic achievement if only they enjoy reading which will lead to understanding the subject. Furthermore different students have different academic objective. Some students wanted to score high mark in all subjects, some just wanted to pass and there are students who are not interested because students study unwillingly. This can also be the reasons for students to practice different study habits in different level.

\section{Implication of Study}

It is the believe of the researcher that this study will be very meaningful for the health science students, lecturer, Student's Affair Department as well as the Management of MUCH despite this study was done for the first time to identify the relationship between study habits and the academic achievement of the health science students. This finding will help the lecturers to identify the weak students and to assist them in developing effective study habits to improve the student's academic performance. Besides that it will also give opportunity to the Student's Affair Department of MUCH to develop new programs in order to motivate the students to increase their CGPA every semester.

Students sometime will take longer time to get used with the study habit that newly introduced to them. Students need to know the important of practicing the study habits. Students cannot get good result just by applying the study habits but they should know the correct way to practice it. Since all 
the study habits practiced by the health science students did not assist them to perform better academically, it is important to identify different study habits besides the study habits mentioned in this research to determine the study habits which can contribute to the health science students academic achievement.

\section{Recommendation}

This finding is expected to provide information to the health science students in different study habit technique which led to their academic achievement. Student's Affairs Department and lecturers of MUCH should take note of these results in monitoring the student's grade for every semester. Good students need to be identified and study habit practiced by them can be suggested to the average and below average students so that they can achieve good grade as well.

\section{Students' Affair Department}

Student's Affair Department should observe closely on the students mark for every semester. Below average students have to be identified. This department have to generate a program particularly for the below average students in order to identify their weak element in terms of study habit. Probably there are students who study hard but could not score high just because the methods they using is not the proper one. Therefore this special programs conducted for them can be beneficial in providing them good study habit methods which will help them to increase their GCPA for coming semesters. Thus, the Student's Affair Department also needs to work closely with the lecturers and Exam Department of MUCH.

\section{Health Science Lecturers}

Lecturers need to work together with Students Affair Department in identifying the average and below average students. Average students can be called for mentor mentee session handled by the lecturers in order to recognize problem in the students study habit methods. However, the below average students can be identified and send to the special program conducted by the Student's Affair Department. All the students who need help can be identified by the lecturers through test, midterm, assignments and final exam handled by them. Besides that the lecturers can conduct extra classes for the weak students. This extra class will help the lecturers to concentrate on individual students and their problem. Other than that, reward system can also be a motivation to the below average students to achieve good grade. This reward can be gifts, marks or encouraging words in front of the classroom.

\section{Recommendation to Future Research}

This research was conducted in Masterskill University College of Health Sciences, Cheras Campus. Future researchers can extent studies to other branches of $\mathrm{MUCH}$. Besides that this study can also be extended to other health science colleges in order to get a complete view of study habit method practiced by the health science students.

Findings of this study indicate that Method of Study had significant relationship between academic achievements of the health science students but do not assist the students to get better result. Thus, it is recommended to future researchers to study on the different variables under Method of Study and to discover study habits which will assist the students to increase their academic performance. 
INTERNATIONAL JOURNAL OF ACADEMIC RESEARCH IN BUSINESS AND SOCIAL SCIENCES

Vol. 8, No. 7, July 2018, E-ISSN: 2222-6990 @ 2018 HRMARS

\section{References}

Creswell, J. W. (2005). Educational research: Planning, conducting, and evaluating quantitative and qualitative research (2nd ed.). Upper Saddle River, NJ: Pearson Education.

Chamorro-Premuzic, T. \& Furnham, A. (2003a). Personality predicts academic performance: evidence from two longitudinal university samples. Journal of Research in Personality, 37, 319-338. https://doi:10.1016/S0092-6566(02)00578.

Jan, W., Kuzma, S. (2004). Basic Statistics for the Health Sciences. $5^{\text {th }}$, Edition, Mc Graw Hill, Higher Education.

Kathleen, M. T. Collins. (2006). Reading Ability as a Predictor of African-American Graduate Students' Writing Proficiency in the Context of Statistics Cources. University of Arkansas At Fayetteville, United States. Retrieved from http://iaseweb.org/documents/paper/icots/C319.pdf

Menzel, W. E. (1982). How to study effectively. London:Oxford University Press.

Rasul, G. (1968). An Investigation into the study habits among first year students in the WPAU, Layallpur. M.Ed. Thesis, Department of Agricultural Education, WPAU, Layallpur.

Raymond, W. P. \& Barbara, M. G. (1997). Receiver Apprehension, Edicational Attitudes, and Study Habits.

Rana, S. A. \& Rukhsana, K. (2011). Comparison of Study Habits and Academic Performance of Pakistani British and White British Students. GC University, Lahore \& Punjab University, Lahore. Retrieved from www.gcu.edu.pk/FullTextJour/PJSCS/2011/4.pdf

Shafiq, M. (1979). Effect of study habits on the achievements of M.Sc. students in the University of Agriculture, Faisalabad. M.Sc. Thesis, Department of Agricultural Education, University of Agriculture, Faisalabad.

Sorenson, H.P. (1991). Psychology in Education. McGraw Hill Book Co. Inc, New.York., USA.

Study Skill Assessment Questionnaire.(2008). Department of Counseling Services, University of Houston Clear Lake, Texas. Retrieved from http://www.uhcl.edu/counselingservices.

Tom Lang, M. A. (2003). Common Statistic Errors Even You Can Find. Part 1: Errors in Descriptive Statistics and In Interpreting Probability Values. MWA Journal, Vol. 18, No.2, 2003. Retrieved from www.or.org/files/Statistical\%20Errors\%20Part\%201.pdf 